\title{
REGULARITIES OF OXIDATIVE STRESS COURSE IN CEREBRAL STROKE
}

\author{
Ekaterina Vladimirovna Silina ${ }^{1}$, Sofia Alekseevna Rumyantseva², Victor Aleksandrovich Stupin², Vasily Vladimirovich Afanasiev ${ }^{3}$, \\ Natalia Ivanovna Menshova ${ }^{1}$, Sergej Brankovich Bolevich ${ }^{1}$ \\ ${ }^{1}$ First Moscow State Medical University (Sechenov University) Moscow, Russia \\ ${ }^{2}$ Russian National Research Medical University Moscow, Russia \\ ${ }^{3}$ North-Western State Medical University, St. Petersburg, Russia

\section{SMER I TOK PROCESA OISIDATIVNOG STRESA} \\ PRI CEREBROVASKULARNOM UDARU \\ Ekaterina Vladimirovna Silina ${ }^{1}$, Sofia Alekseevna Rumyantseva², Victor Aleksandrovich Stupin², Vasily Vladimirovich Afanasiev ${ }^{3}$ \\ Natalia Ivanovna Menshova ${ }^{1}$, Sergej Brankovich Bolevich \\ ${ }^{1}$ Prvi moskovski drzavni medicinski univerzitet, Univerzitet Sečenov, Moskva, Rusija \\ ${ }^{2}$ Ruski nacionalni medicinski istraživački centar, Univerzitet u Moskvi, Rusija \\ Severozapadni državni medicinski univerzitet, St. Petersburg, Rusija
}

Received / Primljen: 14. 11. 2017

Accepted / Prihvaćen: 15. 11. 2017.

\section{ABSTRACT}

Objective of the article: to improve diagnosis and treatment results of patients with ischaemic and haemorrhagic strokes by means of a comprehensive in-depth review of free radical processes and the defining of patterns of their course under the conditions of stroke. During the study, the authors established the regularities for the course of free radical processes in stroke with the development of oxidative stress and the severity of peroxidelipid component, which increases in proportion to the severity of ischaemic or haemorrhagic stroke with maximum intensity in cases of adverse outcomes. Multi-stage mathematical modelling allowed for the determination of a highly effective formula for early stroke prognosis, which includes only 5 indicators used for estimation at hospitalization: consciousness level, blood glucose level, number of leukocytes in venous blood, antiperoxide activity of plasma and malondialdehyde. It was found that each of these parameters is an independent marker of hospital mortality. The consideration of all these indicators makes it possible to carry out early prognostic diagnostics with $90 \%$ probability and to timely correct treatment. We have also established digital boundaries, which are indications for the administration of energy correct therapy, the proper implementation of which has significantly improved the results of hospital treatment.

Keywords: stroke, oxidative stress, apoplectic attack, free radical processes, early prediction, predicative model.

\section{SAŽETAK}

Cilj ovog rada je poboljšanje dijagnoze $i$ ishoda tretmana pacijenata sa ishemijskim $i$ hemoragijskim moždanim udarom sa osvrtom na patofiziološke mehanizme nastanka posredstvom slobodnoradikalskih procesa kao smera tih procesa u pomenutim stanjima. U ovoj studiji, autori su ustanovili važnost slobodnih radikala u generisanju oksidativnog stresa i proceni stepena lipidne peroksidacije, cija je produkcija proporcionalna težini ishemijskog ili hemoragijskog udara kao i prisustvu negativnih komplikacija. Multidimenzionalna matematička jednačina nam je omogućila procenu prognozu i praćenje ovih pacijenata, koja se zasniva na 5 indikatora procene pri hospitalizaciji: stanje svesti, nivo glukoze u krvi, broj leukocita u krvi, antiperoksidna aktivnost markera plazme i nivo malonildiladehida. Utvrdeno je da je svaki od ovih pet indikatora nezavistan marker hospitalnog mortaliteta. Uzimanje u obzir svih ovih indikatora omogućava rano dijagnostikovanje u 90\% slučajeva i blagovremeno lečenje. Pored toga, utvrdili smo digitalne granice, koje su indikaciono područje za primenu energetske terapije, kao značajne smernice koja može poboljšati rezultate bolničkog lečenja.

Kljucne reci: moždani udar, oksidativni stres, apopleksija, slobodnoradikalski proces, rano prepoznavanje, model predvidanja
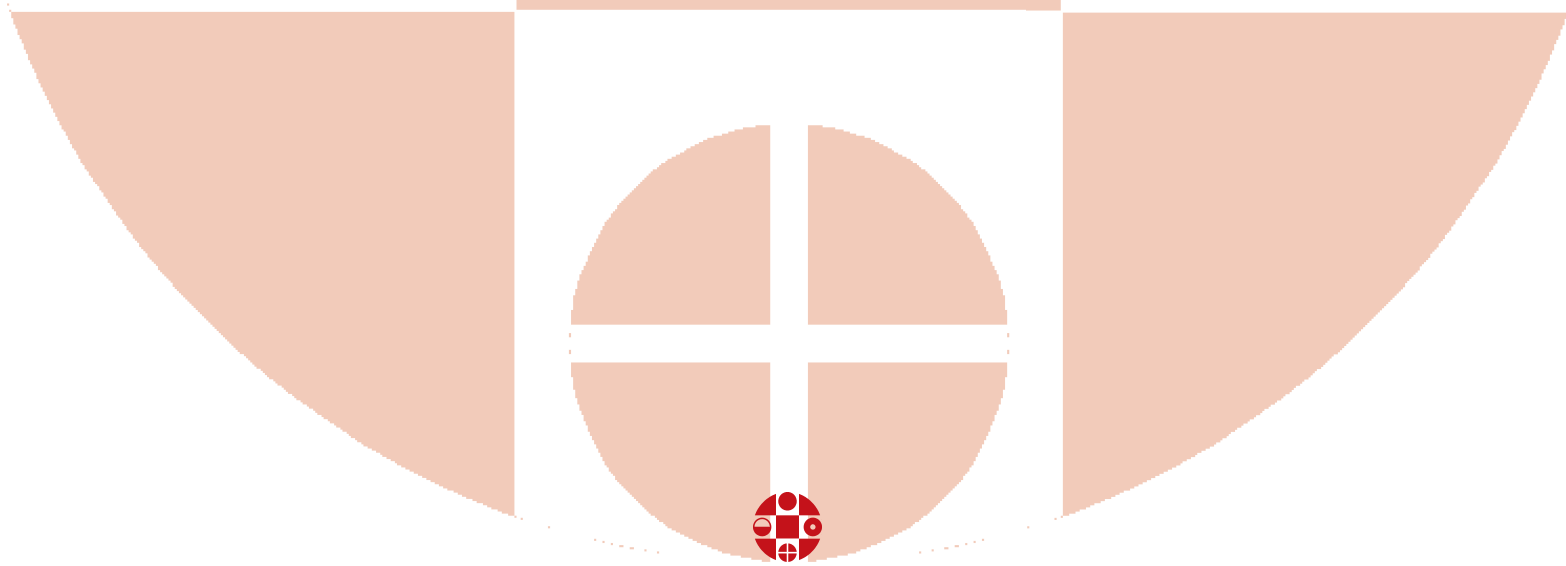


\section{INTRODUCTION}

Oxidative stress is an important component of many serious diseases [Liu Z, Zhou T, Ziegler AC, 2017; Bjørklund, G., Chirumbolo, S., 2016], and it also plays a role in the process of ageing [Bonomini, F., Rodella, L.F., Rezzani, R, 2015]. It has been proven that the imbalance of free radical processes (FRP) with the predominance of one of its components (oxidative stress) leads to accumulation of pathological genetic aberrations [Wang D, Feng JF, Yuan GY et al. 2017; Vijayalakshmi, P., Geetha, C.S., Mohanan, P.V., 2013] and provokes inflammation [8-9] and disorders of different organs and body system functioning [Azizova, O.A., Gao, L.N., Dumikyan, A.Sh. et al. 2011; Silina, E.V., Rumyantseva, S.A., Bolevich, S.B. et al. 2011; Asmat, U., Abad, K., Ismail, K., 2016]. It is known that the development of acute conditions, including socially significant diseases, is often preceded by a long asymptomatic stage, during which the parameters of FRP change [Aliev, N.A., Bobiev, A.B., Khamidov, D.B. et al. 2015; Giam, B., Kaye, D.M., \& Rajapakse, N.W., 2016]. At the same time, many molecular mechanisms of cell pathology foundations during the development and treatment of major socially significant diseases, (the main of which is cerebral stroke), still remain unstudied [Chatzopoulos A, Tzani AI, Doulamis IP et al. 2017].

For a long time during the study of free radical cells and tissue damage, oxidative stress was considered only in terms of ascertaining facts about changes in levels of certain parameters, without revealing the patterns of their dynamics [Chehaibi K, Trabelsi I, Mahdouani K, Slimane MN, 2016, Žitňanová I, Šiarnik P, Kollár B et al. 2016]. There is no unified approach to the use of FRP parameters, as prognosis markers, and assessing the feasibility and effectiveness of conducting various types of corrective therapy [Chamorro Á, Dirnagl U, Urra X, 2016]. Stroke is the leading cause of disability in the population and the second cause of mortality in the world [Strong, K., Mathers, C., Bonita, R., 2007]. This prevalence makes stroke the most important problem not only for clinical angioneurology but also as a key social problem, which requires the development of maximally effective treatment methods, based on a comprehensive study of pathogenesis aspects.

The aim of this scientific work is to develop a pathophysiological-ly based strategy for treating patients with stroke, based on studying the regularities of FRP course.

\section{MATERIALS AND METHODS}

During the study, we conducted a prospective clinicalinstrumental study, which included 383 patients with acute stroke verified by tomography (CT/MRI). In 302 (78.9\%) cases, patients had ischaemic stroke (IS), and in 81 (21.1\%) cases patients had haemorrhagic stroke (HS). In addition to stroke, $96 \%$ of patients had other cardiovascular disease diagnoses, which indicate a high level of vascular comor- bidity. The distribution of patients by sex, age, nature and severity of disease is presented in Table 1. From the table below, it can be seen that HS is a significantly more serious disease than IS.

All patients were hospitalized in the intensive care unit and received complex therapy. When included in the study, patients were divided into two groups: 106 patients received standard therapy, and 277 patients additionally received EC therapy; Ascorbic Acid (AA) - 97 (32.1\%) patients with IS and 23 (28.4\%) patients with HS; Cytoflavin - 67 (22.2\%) patients with IS and $32(39.5 \%)$ patients with HS; Reamberin - 9 (3.0\%) patients with IS; Ethylmethyl hydroxypiperidine succinate - 29 (9.6\%) patients with IS and $11(13.6 \%)$ patients with HS. A combination of two or more energy-correctors was provided to $52(17.2 \%)$ patients with IS and 14 (17.3\%) with HS. Patient groups were comparable at the time of hospitalization (Table 2).

All patients underwent clinical and instrumental monitoring in dynamics (until day 21 of hospitalization), which included the study of anamnesis and complaints, clinical somatic monitoring with daily monitoring of blood pressure, heart rate, respiratory rate and body temperature. Neurological status, which includes the consciousness disorder level and motor deficiency, was estimated in detail according to Glasgow Coma Scale (GCS), NIH, the Bartel social adaptation index and the Rankin modified scale. MRT/CT scan of the brain was conducted on all patients during the first hours after hospitalization; thereafter, 34 patients with IS additionally underwent CT/MRT in dynamics; on the $1^{\text {st }}, 5^{\text {th }}$ and $20^{\text {th }}$ day in T1, T2 and Flair regimens, respectively. The data on blood and urine analysis, biochemical analysis, coagulograms and the acid-base state of arterial and venous blood were studied in dynamics. Additionally, we also examined the FRP in blood plasma in dynamics. FRP were studied in terms of generation of active oxygen forms (GAOF) by: leukocytes, the indicators of basal chemiluminescence intensity (CLIb) and zymosan-stimulated chemiluminescence intensity (CLIs), the activity coefficient (AC), spontaneous chemiluminescence (SpCL) and hydrogen peroxide-induced chemiluminescence (IndCL) of secondary plasma, antiperoxide plasma activity (APA), and by-products of lipid peroxidation (LPO), the main component of which, is malondialdehyde (MDA). The values studied in 33 cases of healthy people and donors were taken as the normal index for FRP.

The statistical processing of data was carried out using the SPSS 17.0 and Statistica 6.0 programmes with implementation of standard parametric and nonparametric criteria for assessing significant differences. The differences were considered to be significant at $p<0.05$. The descriptive statistics of qualitative parameters are presented in the form of frequencies (abs, \%), while the quantitative parameters are presented, in the form of the median $(\mathrm{Me})$ and average \pm standard deviation; these parameters include the lower and upper quartile, in case a parameter had a far non-normal distribution function. To compare two independent nonparametric samples, we used the 
Table 1. Characteristic of patients with apoplectic attack.

\begin{tabular}{|c|c|c|c|}
\hline Characteristic & Ischaemic stroke $(\mathrm{n}=302)$ & Haemorrhagic stroke $(\mathrm{n}=81)$ & Overall $(n=383)$ \\
\hline $\begin{array}{l}\text { Average age*, years }(\mathrm{M} \pm \mathrm{m}) \\
\text { Min-max }\end{array}$ & $\begin{array}{l}65.06 \pm 10.32 \\
36-87 \\
\end{array}$ & $\begin{array}{l}61.01 \pm 13.77 \\
28-94\end{array}$ & $\begin{array}{l}63.20 \pm 12.54 \\
28-94 \\
\end{array}$ \\
\hline $\begin{aligned} \text { Sex/age*: - male } & \\
& \text { - female }\end{aligned}$ & $\begin{array}{l}159 \text { (52.7\%), } 63 \text { у.о. } \\
143 \text { (47.3\%), } 69 \text { у.о. }\end{array}$ & $\begin{array}{l}45 \text { (55.6\%), } 52 \text { y.о. } \\
36 \text { (44.4\%), } 67 \text { y.о. }\end{array}$ & $\begin{array}{l}204 \text { (53.3\%), } 59 \text { y.o. } \\
179 \text { (46.7\%), } 69 \text { y.o. }\end{array}$ \\
\hline $\begin{array}{l}\text { Duration of hospitalization*: } \\
<6 \text { hours } \\
6-24 \text { hours } \\
24-48 \text { hours } \\
>48 \text { hours }\end{array}$ & $\begin{array}{l}57(18.87 \%) \\
70(23.18 \%) \\
91(30.13 \%) \\
84(27.82 \%)\end{array}$ & $\begin{array}{l}24(29.63 \%) \\
26(32.10 \%) \\
21(25.92 \%) \\
10(12.35 \%)\end{array}$ & $\begin{array}{l}81(21.15 \%) \\
96(25.07 \%) \\
112(29.24 \%) \\
94(24.54 \%) \\
\end{array}$ \\
\hline $\begin{array}{l}\text { Consciousness level*: } \\
\text { - intact } \\
\text { - sleepiness } \\
\text { - somnolentia } \\
\text { - semi-coma } \\
\text { - coma }\end{array}$ & $\begin{array}{l}221(73.18 \%) \\
24(7.95 \%) \\
25(8.28 \%) \\
21(6.95 \%) \\
11(3.64 \%) \\
\end{array}$ & \begin{tabular}{|l|}
$34(41.98 \%)$ \\
$12(14.81 \%)$ \\
$9(11.11 \%)$ \\
$19(23.46 \%)$ \\
$7(8.64 \%)$ \\
\end{tabular} & $\begin{array}{l}255(66.58 \%) \\
36(9.40 \%) \\
34(8.88 \%) \\
40(10.44 \%) \\
18(4.70 \%) \\
\end{array}$ \\
\hline Scope of damage (according to CT/MRT data) & $\begin{array}{l}<10 \mathrm{~cm}^{3}-107(35.4 \%) \\
10-50 \mathrm{~cm}^{3}-106(35.1 \%) \\
>50 \mathrm{~cm}^{3}-89(29.5 \%)\end{array}$ & $\begin{array}{l}<10 \mathrm{~cm}^{3}-22(27.2 \%) \\
10-30 \mathrm{~cm}^{3}-31(38.3 \%) \\
>30 \mathrm{~cm}^{3}-28(34.5 \%) \\
\end{array}$ & $\begin{array}{l}129(33.7 \%) \\
137(35.8 \%) \\
117(30.5 \%) \\
\end{array}$ \\
\hline Arterial hypertension & $291(96.69 \%)$ & $75(92.59 \%)$ & $366(95.56 \%)$ \\
\hline CHD, Cardiosclerosis & $212(70.20 \%)$ & $52(64.20 \%)$ & $264(69.92 \%)$ \\
\hline Pneumofibrosis, emphysema & $106(35.10 \%)$ & $27(33.33 \%)$ & $133(34.73 \%)$ \\
\hline Ciliary arrhythmia * & $93(30.79 \%)$ & $7(8.64 \%)$ & $100(26.11 \%)$ \\
\hline Diabetes mellitus * & $78(25.83 \%)$ & $9(11.11 \%)$ & $87(22.72 \%)$ \\
\hline Obesity* & $63(20.86 \%)$ & $8(9.88 \%)$ & $71(18.54 \%)$ \\
\hline Postinfarction cardiosclerosis * & $57(18.87 \%)$ & $5(6.17 \%)$ & $62(16.19 \%)$ \\
\hline Stenocardia & $45(14.90 \%)$ & $10(12.35 \%)$ & $55(14.36 \%)$ \\
\hline GIT diseases & $41(13.57 \%)$ & $13(16.05 \%)$ & $54(14.10 \%)$ \\
\hline Repeated Acute Cerebrovascular Event * & $55(18.21 \%)$ & $4(4.94 \%)$ & $59(15.40 \%)$ \\
\hline
\end{tabular}

Note: * - the difference between groups is significant, $\mathrm{p}<0.05$

Table 2. Groups of patients with apoplectic attack.

\begin{tabular}{|c|c|c|c|c|c|c|c|c|c|}
\hline & \multicolumn{2}{|c|}{ Ischaemic stroke $(\mathrm{n}=302)$} & \multirow[t]{2}{*}{$\mathrm{p}$} & \multicolumn{2}{|c|}{ Haemorrhagic stroke $(n=81)$} & \multirow[t]{2}{*}{$\mathrm{p}$} & \multicolumn{2}{|c|}{ Overall $(n=383)$} & \multirow[t]{2}{*}{$\mathrm{p}$} \\
\hline & $\begin{array}{c}\text { Group I } \\
(\mathrm{n}=81)\end{array}$ & $\begin{array}{c}\text { Group II } \\
(\mathrm{n}=221)\end{array}$ & & $\begin{array}{c}\text { Group I } \\
(\mathrm{n}=25)\end{array}$ & $\begin{array}{c}\text { Group II } \\
(\mathrm{n}=56)\end{array}$ & & $\begin{array}{l}\text { Group I } \\
(\mathrm{n}=106)\end{array}$ & $\begin{array}{c}\text { Group II } \\
(\mathrm{n}=277)\end{array}$ & \\
\hline Average age & $66.8 \pm 1.1$ & $64.1 \pm 0.7$ & 0.120 & $59.8 \pm 1.5$ & $62.2 \pm 1.5$ & 0.265 & $63.4 \pm 1.0$ & $63.1 \pm 0.8$ & 0.576 \\
\hline $\begin{array}{l}\text { Sex: -male } \\
\text {-female }\end{array}$ & $\begin{array}{l}44(53.3 \%) \\
37(45.7 \%) \\
\end{array}$ & $\begin{array}{l}115(52.0 \%) \\
106(48.0 \%)\end{array}$ & 0.624 & $\begin{array}{l}13(52.0 \%) \\
12(48.0 \%) \\
\end{array}$ & $\begin{array}{l}32(57.1 \%) \\
24(42.9 \%) \\
\end{array}$ & 0.851 & $\begin{array}{l}57(53.8 \%) \\
49(46.2 \%) \\
\end{array}$ & $\begin{array}{l}147(53.1 \%) \\
130(46.9 \%)\end{array}$ & 0.993 \\
\hline $\begin{array}{c}\text { Admission: } \\
<24 \mathrm{~h} \\
24-48 \mathrm{~h} \\
>48 \mathrm{~h}\end{array}$ & $\begin{array}{l}28(34.6 \%) \\
27(33.3 \%) \\
26(32.1 \%) \\
\end{array}$ & $\begin{array}{l}99(44.8 \%) \\
64(29.0 \%) \\
58(26.2 \%) \\
\end{array}$ & 0.275 & $\begin{array}{c}15(60.0 \%) \\
7(28.0 \%) \\
3(12.0 \%) \\
\end{array}$ & $\begin{array}{c}35(62.5 \%) \\
14(25.0 \%) \\
7(12.5 \%) \\
\end{array}$ & 0.960 & $\begin{array}{l}43(40.6 \%) \\
34(32.1 \%) \\
29(27.3 \%) \\
\end{array}$ & $\begin{array}{c}134(48.4 \%) \\
78(28.2 \%) \\
65(23.4 \%) \\
\end{array}$ & 0.389 \\
\hline $\begin{array}{l}\text { Conscious } \\
\text { alteration of } \\
\text { consciousness }\end{array}$ & $\begin{array}{l}57(70.3 \%) \\
24(29.6 \%)\end{array}$ & $\begin{array}{c}164(74.2 \%) \\
57(25.8 \%)\end{array}$ & 0.603 & $\begin{array}{l}11(44.0 \%) \\
14(56.0 \%)\end{array}$ & $\begin{array}{l}23(41.1 \%) \\
33(58.9 \%)\end{array}$ & 0.978 & $\begin{array}{l}68(64.2 \%) \\
38(35.8 \%)\end{array}$ & $\begin{array}{c}187(67.5 \%) \\
90(32.5 \%)\end{array}$ & 0.616 \\
\hline $\begin{array}{c}\text { Volume- }\left(\mathrm{cm}^{3}\right): \\
\text { Me } \\
25 \% / 75 \% \text { Q } \\
\mathrm{N}(\%):<10 \\
10-30 / 50>30 / 50\end{array}$ & $\begin{array}{c}38.46 \pm 7.51 \\
11.70 \\
2.40 / 39.56 \\
26(32.1 \%) \\
30(37.0 \%) \\
25(30.9 \%)\end{array}$ & $\begin{array}{c}34.83 \pm 3.8 \\
17.26 \\
1.58 / 50.78 \\
81(36.7 \%) \\
76(34.4 \%) \\
64(28.9 \%)\end{array}$ & 0.764 & $\begin{array}{c}37.96 \pm 5.26 \\
27.58 \\
11.64 / 51.18 \\
7(28.0 \%) \\
9(36.0 \%) \\
9(36.0 \%)\end{array}$ & $\begin{array}{c}28.23 \pm 2.57 \\
24.80 \\
13.76 / 38.90 \\
15(26.8 \%) \\
22(39.3 \%) \\
19(33.9 \%)\end{array}$ & 0.961 & $\begin{array}{c}38.29 \pm 5.1 \\
20 / 51 \\
7.52 / 51.00 \\
33(31.1 \%) \\
39(36.8 \%) \\
34(32.1 \%)\end{array}$ & $\begin{array}{c}31.9 \pm 3.1 \\
20.87 \\
4.59 / 47.18 \\
96(34.6 \%) \\
98(35.4 \%) \\
83(30.0 \%)\end{array}$ & 0.804 \\
\hline
\end{tabular}

Mann-Whitney test, while for multiple comparisons we used the Kruskal-Wallis test. To compare two dependent nonparametric samples, we used the Wilcoxon signedrank test, and for the multiple comparisons we used the Friedman test. The qualitative variables were compared using the $x^{2}$ test (Pearson's chi-squared test, for the analysis of contingency tables). The stratification of obtained results was carried out by multifactor analysis, the basis of which was the correlation matrix (Pearson and Spearman methods). To build this matrix, we determined the characteristic values and corresponding vectors with correlation coefficients $\mathrm{r}>0.2 ; \mathrm{p}<0.05$. To determine important factors, we used the principal component method. The number of counted complexes was determined by means 
of a point chart of normalized stress, which estimates the total weight of variables included in the complex. To select indicators with a high factor load, we used the Varimax orthogonal rotation method. The prognostic modelling was carried out using discriminant analysis and binary logistic regression. Differences were considered to be significant, when $\mathrm{p}<0.05$.

\section{RESULTS}

Positive significant imbalance of FRP was detected on the $1^{\text {st }}$ day of hospitalization of patients with stroke; however, the degree of severity and the direction of this imbalance varied (Table 3). It was established that among the patients with acute IS, the imbalance of FRP mainly affects the peroxide-lipid component markers in the form of a reliable increase in the MDA indicators average of 1.27 times $(\mathrm{p}<0.01), \mathrm{SpCL}-1.05$ times $(\mathrm{p}<0.05)$ and IndCL -1.23 times ( $<<0.001)$. The level of APA among patients with IS was reliably $(\mathrm{p}<0.05)$ reduced on average 1.07 times. In contradistinction from patients with IS, when hospitalized, patients with HS were diagnosed with an increase in oxygen markers: CLIb -1.27 times $(\mathrm{p}<0.01)$ and CLIs -1.42 times $(\mathrm{p}<0.01)$. At the same time, patients with HS had a marked imbalance and lipid components of FRP in the form of a significant increase in the level of MDA by 1.36 times $(\mathrm{p}<0.01)$, SpCL -1.11 times $(\mathrm{p}<0.001)$ and IndCL -1.32 times ( $<<0.001$ ); in the background, a decrease in APA of 1.15 times $(\mathrm{p}<0.01)$ occurred. The comparative analysis of FRP indexes among patients with strokes of a different nature revealed significant differences, mainly in markers of oxygen stages; according to CLIb ( $p<0.001$ ), which on average was $45 \%$ higher among patients with $\mathrm{HS}$, $\mathrm{AC}(\mathrm{p}<0.01)$ was $55 \%$ higher among patients with IS, and SpCL index $(\mathrm{p}<0.05)$ was $26 \%$ more under HS. As to the other markers, we have noted the tendencies for more pronounced imbalances of all FRP and HS stages, the pathogenesis of which is more multifaceted.

The consolidated mechanism was the aggravation of free radical imbalance, as the condition of the patient became more severe, with the displacement of the disregulation vector into the peroxide-lipid side. Thus, the level of consciousness disorders, as the main clinical criterion of severity, were chosen for the patients with stroke. In the patients with moderate IS, who were admitted into the hospital without signs of altered consciousness, the parameters of the oxygen stages of FRP significantly exceeded the norm: CLIs on average by 1.18 times $(\mathrm{p}<0.05)$ and IndCL - by 1.25 times $(\mathrm{p}<0.001)$. The patients with severe IS, who had a consciousness disorder when hospitalized, were diagnosed with a significant increase in the parameters of

Table 3. Imbalance of free radical processes in critical states of different genesis.

\begin{tabular}{|c|c|c|c|c|c|}
\hline FRP OXYGEN markers & $\begin{array}{l}\text { CLIb } \\
\left(\mathrm{mV} / \mathrm{sec} \times 10^{6} \mathrm{~L}\right)\end{array}$ & \multicolumn{2}{|l|}{$\begin{array}{l}\text { CLIs } \\
\left(\mathrm{mV} / \sec \times 10^{6} \mathrm{~L}\right)\end{array}$} & \multicolumn{2}{|c|}{$\begin{array}{l}\text { Activity ratio } \\
\text { (CLIs/CLIb) }\end{array}$} \\
\hline Health $(n=33)$ & $\begin{array}{l}63.37 \pm 5.04 \\
62.50 \\
41.61 / 80.30\end{array}$ & \multicolumn{2}{|l|}{$\begin{array}{l}435.83 \pm 32.49 \\
469.85 \\
307.55 / 564.43\end{array}$} & \multicolumn{2}{|c|}{$\begin{array}{l}8.28 \pm 1.19 \\
6.89 \\
3.99 / 11.01\end{array}$} \\
\hline Stroke $(n=383)$ & $\begin{array}{l}91.14 \pm 7.39 \\
64.23 \\
37.10 / 136.18\end{array}$ & \multicolumn{2}{|l|}{$\begin{array}{l}774.89 \pm 54.96 \\
\mathbf{5 7 1 . 3 0} \% \\
322.20 / 1186.00\end{array}$} & \multicolumn{2}{|c|}{$\begin{array}{l}10.41 \pm 2.05 \\
6.70 \\
3.11 / 12.02\end{array}$} \\
\hline Ischaemic stroke $(\mathrm{n}=302)$ & $\begin{array}{l}87.89 \pm 7.65 \\
54.90 \\
23.24 / 125.70\end{array}$ & \multicolumn{2}{|l|}{$\begin{array}{l}721.81 \pm 61.17 \\
544.50 \\
264.40 / 1245.00\end{array}$} & \multicolumn{2}{|c|}{$\begin{array}{l}14.67 \pm 3.19 \\
7.65 \\
4.08 / 22.02\end{array}$} \\
\hline Haemorrhagic stroke $(n=81)$ & $\begin{array}{l}119.05 \pm 12.04 \\
79.45 * \\
49.99 / 160.58\end{array}$ & \multicolumn{2}{|l|}{$\begin{array}{l}781.66 \pm 70.39 \\
\mathbf{6 6 7 . 2 0} \% \\
404.35 / 1028.50\end{array}$} & \multicolumn{2}{|c|}{$\begin{array}{l}7.32 \pm 1.20 \\
4.94 \\
3.02 / 9.19\end{array}$} \\
\hline ALKALINE-LIPIDIC & $\begin{array}{l}\text { SpCL of the } \\
\text { secondary plasma }\end{array}$ & $\begin{array}{l}\mathrm{H}_{2} \mathrm{O}_{2} \text { IndCL of the } \\
\text { secondary plasma }\end{array}$ & IndCL/SpC & (k/APA) & $\begin{array}{l}\text { MDA } \\
(\mu \mathrm{M})\end{array}$ \\
\hline Health $(n=33)$ & $\begin{array}{l}0.820 \pm 0.013 \\
M e=0.802 \\
0.788 / 0.857\end{array}$ & $\begin{array}{l}2.13 \pm 0.10 \\
M e=2.09 \\
1.62 / 2.48\end{array}$ & $\begin{array}{l}2.73 \pm 0.14 \\
M e=2.78 \\
2.06 / 3.19\end{array}$ & & $\begin{array}{l}2.92 \pm 0.17 \\
M e=2.75 \\
2.52 / 3.70\end{array}$ \\
\hline Stroke $(n=383)$ & $\begin{array}{l}0.854 \pm 0.007 \\
\mathbf{0 . 8 5 0} \% \\
0.803 / 0.929\end{array}$ & $\begin{array}{l}2.77 \pm 0.05 \\
2.62 \% \\
2.11 / 3.30\end{array}$ & $\begin{array}{l}3.25 \pm 0.08 \\
3.02 * \\
2.55 / 3.98\end{array}$ & & $\begin{array}{l}3.75 \pm 0.11 \\
\mathbf{3 . 6 0} \% \\
2.89 / 4.47\end{array}$ \\
\hline Ischaemic stroke $(\mathrm{n}=302)$ & $\begin{array}{l}0.857 \pm 0.008 \\
\mathbf{0 . 8 4 0} \% \\
0.793 / 0.910\end{array}$ & $\begin{array}{l}2.73 \pm 0.07 \\
\mathbf{2 . 5 8} \\
2.24 / 3.29\end{array}$ & $\begin{array}{l}3.24 \pm 0.09 \\
2.98 * \\
2.57 / 4.10\end{array}$ & & $\begin{array}{l}3.68 \pm 0.12 \\
\text { 3.49* } \\
2.91 / 4.48\end{array}$ \\
\hline Haemorrhagic stroke $(n=81)$ & $\begin{array}{l}0.889 \pm 0.012 \\
\mathbf{0 . 8 8 9} \% \\
0.812 / 0.952\end{array}$ & $\begin{array}{l}2.93 \pm 1.13 \\
2.75^{*} \\
2.09 / 3.32\end{array}$ & $\begin{array}{l}3.41 \pm 0.16 \\
\text { 3.19* } \\
2.51 / 3.84\end{array}$ & & $\begin{array}{l}4.03 \pm 0.24 \\
\mathbf{3 . 7 4} * \\
2.86 / 4.54\end{array}$ \\
\hline
\end{tabular}



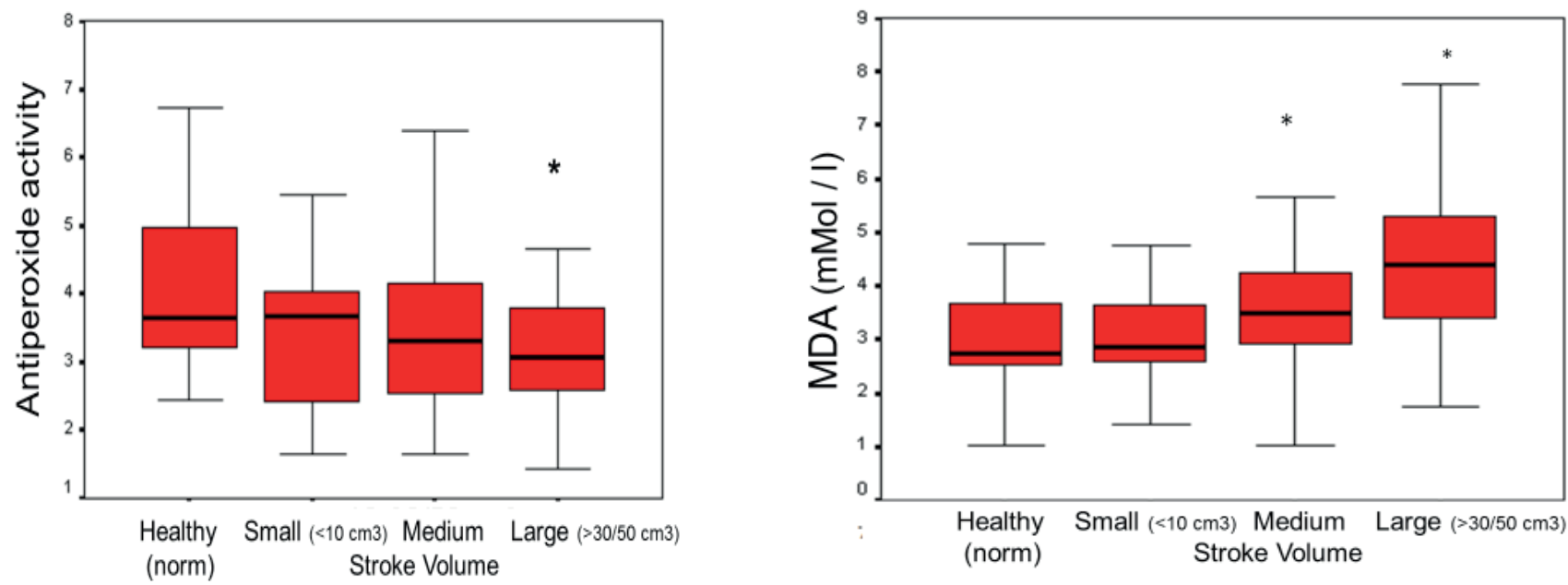

Figure 1. Comparative analysis of TBA-RP (MDA) and k/[IndCL/SpCL] (APA) indicators among patients with stroke of different scopes during hospitalization.

$*-p<0.05$ - difference from the norm

FRP peroxide-lipid component: SpCL - by 1.11 times $(\mathrm{p}<$ $0.01)$, IndCL - by 1.23 times ( $p<0.001)$, IndCL/SpCL - by 1.06 times $(\mathrm{p}<0.05)$ and MDA - by 1.41 times $(\mathrm{p}<0.01)$. On the $1^{\text {st }}$ day of hospitalization, the inhibition activity in oxygen markers among patients with altered consciousness states were registered. The obtained data prove that the defence-adaptive role of active oxygen forms release, as a stimulant of activity of its own antiradical systems, under conditions of ischaemia, as well as the pathological role of uncontrolled hyperactivation of peroxide-lipid component of FRP (increasing MDA with decreasing APA) in cell destruction, death by apoptosis and necrosis. Similar changes were also typical for patients with HS. The comparative analysis of FRP indexes determined the significance of the MDA-titer increasing with the increase in severity of health conditions among patients with HS.

In the case of various types of stroke, the TBA-RP (MDA) and APA levels were taken as an early marker of scope and severity of damage. The results of FRP index analysis for different scopes of brain damage show a gradual aggravation of FRP imbalance severity with a shift towards peroxide processes alongside a decrease in antiradical systems activity under the increased scope of stroke. Thus, with a small IS scope (less than $10 \mathrm{~cm}^{3}$ ), significant changes in the free radical status affected the oxygen part of the oxidative stress spectrum (the increase in CLIs and $\mathrm{AC})$, and thereafter a tendency towards an increase in the defensive APA was noted. With an average scope of IS (10$50 \mathrm{~cm}^{3}$ ), a significant disruption of peroxide lipid markers was observed against the background of APA decrease $(\mathrm{p}<$ $0.05)$, which sharply aggravated with an extensive IS (more than $50 \mathrm{~cm}^{3}$ ), illustrating the MDA-titer increase on average by $60 \%$ and APA depression by $40 \%(\mathrm{p}<0.05)$. In the case of an $\mathrm{HS}$ of more than $30 \mathrm{~cm}^{3}$, the highest imbalance in both the oxygen and peroxide stages of FRP was noted, which led to the progression of secondary ischaemia.
The analysis of FRP characteristics performed among the patients who were admitted to the hospital at different periods from the moment of first appearance of clinical symptoms made it possible to reveal the patterns of free radical imbalance development in the absence of drug correction, as staying at home, the patients did not receive adequate therapy. Mostly, the FRP imbalance was expressed among the patients hospitalized on the $2^{\text {nd }}-3^{\text {rd }}$ day of the disease. At the same time, a gradual change in free radical reactions from oxygen to peroxide lipid in the form of MDA growth was noted against the background of APA decrease with formation of a vicious circle initiated by active oxygen forms and enhanced LPO, i.e., tissue destruction.

The next stage of our study was the differentiation of patients into subgroups with benign (discharged from inpatient department, $\mathrm{n}=305,79.6 \%$ ) and adverse outcomes (hospital mortality, $\mathrm{n}=78,20.4 \%$, including 48 (15.9\%) with IS and $30(37.0 \%)$ with HS). The correlation analysis helped us to determine that the adverse stroke outcome was associated with a high level of neurological insufficiency (according to the NIH scale in dynamics), functional insufficiency (according to Rankin and Bartel scales), depressed level of consciousness, large disease focus (more than 37 $\mathrm{cm}^{3}$ ), coexisting somatic pathology (CHD, cardiosclerosis, body-weight index increase $\left.>30.5 \mathrm{~kg} / \mathrm{m}^{2}\right)$, high diastolic blood pressure figures $(>95 \mathrm{~mm} \mathrm{Hg}$ ), heart rate $(>85 /$ $\mathrm{min})$, and high respiratory rate $(>20 / \mathrm{min})$ at the time of hospitalization and with the prevalence of complications (pneumonia, stress-protective ulcers of digestive haemorrhage (DH), and venous thromboembolism). Standard laboratory markers examined at the time of hospitalization of patients with stroke were significantly $(\mathrm{p}<0.05)$ correlated with death and are given below in Table 4 . The obtained data allowed conducting an interval analysis of these indicators with the following definition of threshold values and the boundaries of low and high risks of death. 
Table 4. Prognosis of the risk of adverse outcome by laboratory parameters during the first day of hospitalization.

\begin{tabular}{|c|c|c|c|}
\hline Index & Low risk & Average risk & High risk \\
\hline Thrombocytes at hospitalization (ths.)* & $<162$ & $162-355.4$ & $>355.4$ \\
\hline Leukocytes at hospitalization* & $<4.9$ & $4.9-16.8$ & $>16.8$ \\
\hline Glucose at hospitalization* & $<4.2$ & $4.2-11.1$ & $>11.1$ \\
\hline Leukocytes at the $1^{\text {st }}$ day* & $<5.3$ & $5.3-14.6$ & $>14.6$ \\
\hline Banded neutrophils at the $1^{\text {st }}$ day $(\%)^{*}$ & $<2$ & $2-11$ & $>11$ \\
\hline Stab neutrophils at the $1^{\text {st }}$ day $(\%)^{*}$ & $<54$ & $54-82$ & $>82$ \\
\hline Lymphocytes (\%)* & $>29$ & $8-29$ & $<8$ \\
\hline ESR at the $1^{\text {st }}$ day $(\mathrm{mm} / \mathrm{h})^{*}$ & $<4$ & $4.0-41.3$ & $>41.3$ \\
\hline Glucose at the $1^{\text {st }}$ day $(\mathrm{mmol} / \mathrm{L})^{*}$ & $<5.1$ & $5.1-15.6$ & $>15.6$ \\
\hline Urea at the $1^{\text {st }}$ day* & $<2.9$ & $2.9-12.3$ & $>12.3$ \\
\hline Direct bilirubin at the $1^{\text {st }}$ day ${ }^{*}$ & $<4.9$ & $4.9-19.5$ & $>19.5$ \\
\hline Lactate dehydrogenase at the $1^{\text {st }}$ day* & & $235.7-833.5$ & $>833.5$ \\
\hline Sodium at the $1^{\text {st }}$ day ${ }^{*}$ & $<129.8$ & $129.8-148.0$ & $>148$ \\
\hline Thrombin time at the $1^{\text {st }}$ day & $<20.50$ & $20.50-31.38$ & $>31.38$ \\
\hline Prothrombin ratio at the $1^{\text {st }}$ day & $>103.5$ & $72.2-103.5$ & $<72.2$ \\
\hline
\end{tabular}

Note: * - significant difference under $p<0.05$ after the outcome of a stroke.

When conducting a comparative background analysis of FRP markers and stroke outcome, it was found that the most pronounced imbalance of free radical status at the $1^{\text {st }}$ day of hospitalization was registered under an adverse outcome. Thus, CLIb was sharply reduced in the case of adverse IS outcome $(p<0.05)$. The adverse HS outcome was characterized by the intensification of CLIb (critical values - $488.24 \mathrm{mV} / \mathrm{s} \times 10^{6}$ leukocytes, above which all cases of HS ended fatally). With CLIs, a tendency towards greater activation was observed in the case of adverse outcomes ( $p$ $>0.05$ ). The outcome model was unambiguously reflected by the indicators of MDA and APA (Table 5). Thus, Ind$\mathrm{CL} / \mathrm{SpCL}$ index at the time of hospitalization was already strongly reduced among deceased patients with IS ( $\mathrm{p}<$ $0.05)$. The critical values of IndCL/SpCL index were 5.87 among patients with IS and 6.09 among patients with HS. The plasma level of MDA was drastically increased among deceased patients $(p>0.05)$ with critical values of MDA: $6.39 \mu \mathrm{mol} / \mathrm{l}$ among patients with IS and $5.41 \mu \mathrm{mol} / \mathrm{l}$ among patients with HS. Exceeding these values reflected the absolute risk of hospital mortality. The performed analysis allows the recommendation of the use of these indicators as the early prognostic markers of stroke course and outcomes.
A comparative analysis of FRP dynamics among patients with stroke of different genesis who received no EC/ AO revealed a marked imbalance of both oxygen and lipid FRP markers throughout the whole period of in-patient follow-up. In the $2^{\text {nd }}-3^{\text {rd }}$ week, when diurnal infusions were replaced by the use of tablets, the tendency towards activation of FRP had been noted.

The analysis of FRP dynamics revealed the following characteristics under IS: rapid activation in the period from the $1^{\text {st }}$ to the $5^{\text {th }}$ day, according to CLIb - by 1.61 times, CLIs - by 2.32 times, and AC - by 2.99 times. Henceforth, there was a regression of indicators with CLIb normalizing, but CLIs and AC did not normalize even by the $20^{\text {th }}$ day. APA significantly increased by the $5^{\text {th }}$ day - by 1.15 times, having a tendency to normalize by the $10^{\text {th }}$ day, while during the period from the $10^{\text {th }}$ to the $20^{\text {th }}$ day, we noted a 1.36-time decrease in APA. MDA throughout the whole follow-up period gradually increased (by 1.11 times) during the period from the $1^{\text {st }}$ to the $20^{\text {th }}$ day.

The dynamics of FRP among patients with HS had the following characteristics: according to CLIb and CLIs, we observed the regression during the period from the $1^{\text {st }}$ to the $10^{\text {th }}$ day by 1.88 and 1.29 times, respectively; AC increased during the period from the $1^{\text {st }}$ to the $5^{\text {th }}$ day by 1.74

Table 5. Prognosis of mortality risk in terms of FRP among patients with stroke of different natures examined on the 1st day of hospitalization.

\begin{tabular}{|l|c|c|c|c|}
\hline & Low risk & Average risk & High risk & Absolute risk \\
\hline IndCL & $1.28-1.84$ & $1.85-4.24$ & $>4.24$ & $>5.18$ \\
\hline IndCL/SpCL (k/APA) & $1.33-1.92$ & $1.93-5.38$ & $>5.38$ & $>6.09$ \\
\hline $\mathrm{MDA}$ & $1.01-1.51$ & $1.52-5.30$ & $>5.30$ & $>6.39$ \\
\hline
\end{tabular}




\section{Standard therapy}

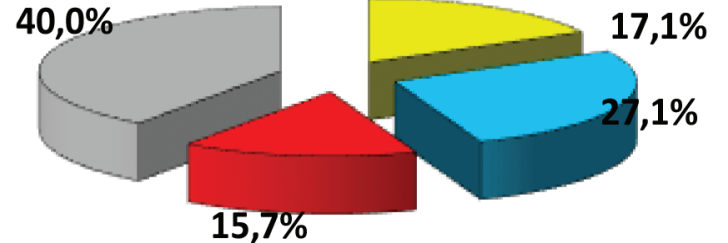

$\square$ Perfect (100 points)

$\square$ Good (80-95 points)

$\square$ Satisfactory (50-75 points)

$\square$ Unfavorable (0-45 points)

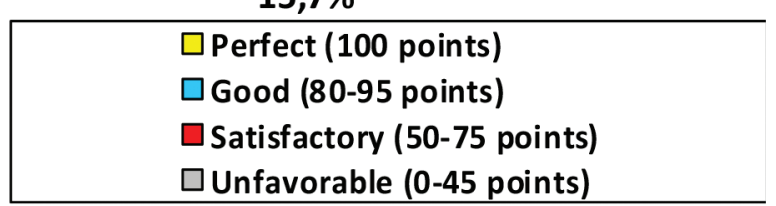

Standard therapy + energy-correcting/antioxidant

therapy

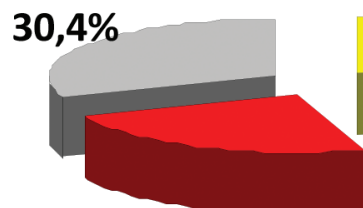

$24,6 \%$

Ischaemic stroke

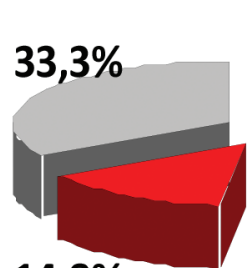

$14,8 \%$

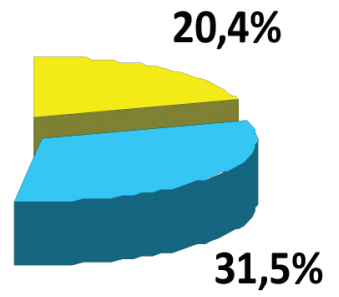

$31,5 \%$

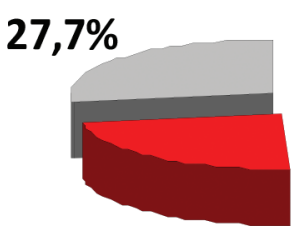

$23,1 \%$
$21,7 \%$

$23,2 \%$
Perfect (100 points)

Good (80-95 points)

Satisfactory (50-75 points)

Unfavorable (0-45 points)

\section{Haemorrhagic stroke}

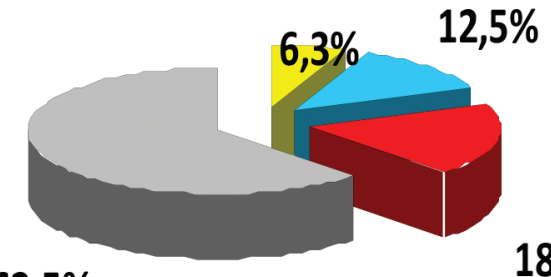

$18,7 \%$
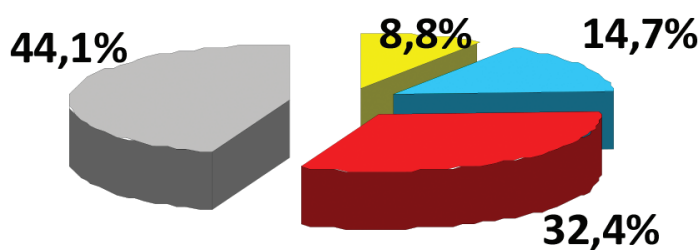

$62,5 \%$

Figure 2. The structure of functional outcomes among patients with strokes of different characteristics according to the Bartel index for the 20th day of hospitalization in groups of patients with and without energy-correcting/antioxidant therapy

times; APA increased in the period from the $1^{\text {st }}$ to the $10^{\text {th }}$ day on average by 1.39 times, normalizing by the $5^{\text {th }}$ day, but during the $10^{\text {th }}-20^{\text {th }}$ day, we noted the APA tended to decrease by 1.15 times; plasma MDA had increased in the period from the $1^{\text {st }}$ to the $5^{\text {th }}$ day by 1.20 times, from the $5^{\text {th }}$ to the $10^{\text {th }}$ day - by 1.13 times, and during the $10^{\text {th }}-20^{\text {th }}$ days - by 1.09 times.

The administration of EC/AO therapy from the very $1^{\text {st }}$ day to patients with stroke of a different genesis led to positive dynamics in FRP. Thus, the pronounced regression of CLIb and CLIs, noticeable already by the $3^{\text {rd }}-5^{\text {th }}$ day, was maintained up to the $7^{\text {th }}-10^{\text {th }}$ day, i.e., up to the moment of the last infusion of energy correctors; this result meant that the production of active forms of oxygen subsided, and their concentration decreased, resulting from the interaction with an antioxidant. The second stage in the positive effect of EC therapy was a decrease in the severity of LPO reactions, which was registered by the dynamics of MDA regression and significant growth of APA by the $3^{\text {rd }}-5^{\text {th }}-7^{\text {th }}$ $10^{\text {th }}$ day. It should be noted that there was a tendency of FRP activation after the end of EC therapy (by the time of discharge), which indicated the need for longer (more than 10 days) EC/AO therapy.

The use of EC therapy not only contributed to the normalization of FRP parameters but also allowed the improvement of the treatment results. The inclusion of EC/AO therapy into the complex therapy of patients with stroke resulted in a more rapid regression (than in the comparative group) of consciousness disturbances $(\mathrm{p}<0.05)$ as well as focal neurologic symptoms with authentically more significant regression by the time of discharge $(\mathrm{p}<0.05)$. 
The final stage of the study was the development of a mathematical model for stroke prognosis. To this end, we used discriminant analysis (DA), and with the help of ,several characteristics, an individual could be assigned to one of the given groups. The DA core was the construction of the discriminant function: $\mathrm{D}=\mathrm{b}_{1} \mathrm{x}_{1}+\mathrm{b}_{2} \mathrm{x}_{2}+\ldots+\mathrm{b}_{\mathrm{n}} \mathrm{x}_{\mathrm{n}}+\mathrm{a}$, where $x_{1}$ and $x_{n}$ were the values of variables that corresponded to the examined cases; $a$ was constant; $\mathbf{b}_{1}-b_{n}$ were coefficients, which were estimated using DA. During the study, we determined the values of D; it was then possible to carry out the division into groups for stroke prognosis with a maximum accuracy.

To form the prognosis model of FRP parameters, we initially used all studied variables: CLIb, CLIs, AC, SpCL, IndCL, APA and MDA. Later, their number was reduced to two (APA, MDA) without critical loss of prognosis significance. Thus, according to the DA results, when $\mathrm{D} \geq 0.55$, the patient fell into the 'adverse outcome' group, and when $\mathrm{D} \leq-0.3$, the patient fell into the 'benign outcome' group. The prognosis accuracy was $68.6 \%(\mathrm{p}<0.05)$.

\begin{tabular}{|l|l|}
\hline \multicolumn{2}{|c|}{$\mathrm{D}=-\mathbf{2 . 6 6 5}+\mathbf{0 . 0 2 1} \mathrm{X}_{1}+\mathbf{0 . 6 7 2 \mathrm { X } _ { 2 }}$} \\
\hline where the constant $=-2.665 ; \mathrm{X}_{1}-\mathrm{APA} ; \mathrm{X}_{2}-\mathrm{MDA}$. \\
\hline Adverse outcome: $\mathrm{D}>0.54[-2 ; 3.5]$ & Benign outcome: $\mathrm{D}<-0.29[-2 ; 1.5]$ \\
\hline
\end{tabular}

However, the obtained accuracy did not satisfy us. Therefore, we later conducted a multifactor analysis of all clinical laboratory parameters assessed in dynamics among patients with stroke. The purpose of this analysis, first, was to detect the persistent correlations between variables, mainly for the further construction of an accurate prognostic model of disease outcome. The initial array of observations was formed on the basis of data from 383 patients with cerebral stroke. At the first step of the factor analysis procedure, we selected 119 indicators (including dynamics up to the $20^{\text {th }}$ day of observation) that had a proven or presumed influence on the course and outcome of stroke, and then we standardized the set values of variables ( $\mathrm{z}$-transformation). Based on the analysis of the total variance, we received 191 factors, including 79 factors excelling in strength; the indexes were grouped by their strengths of influence on the general picture of indicator variability and explained $95.18 \%$ of the total variance. For further exclusion criteria, we used the Cattell scree test, and as a result, we determined 4 HS. After performing 8 rotations by the Varamax method, the significant factors were united into the main components in descending order, which allowed for choosing and reducing them in the future.

Significant multiple correlation coefficients confirmed the descriptiveness and prognosis value of selected clinical and biochemical parameters complemented by the parameters of instrumental methods. Based on the multivariate analysis results, for our further DA and for the future development of an IS prognosis model, we selected the 22 most significant factors studied during the hospitalization of patients and reflected them in the main components, which characterized the outcome (death or discharge):
CLIb, CLIs, AC, APA and MDA; consciousness level by Glasgow Coma Scale (GCS); Bartel index; modified Rankin scale score; NIH; blood pressure; heart rate; white blood cell count; lymphocyte, glucose, thrombocytes, creatinine, urea, potassium, sodium and fibrinogen levels; and ALT, AST, LDH, PTI, INR and prothrombin time. The further step-to-step minimization of their number (up to 5 major factors) allowed for performing DA with reliable accuracy and formulating a mathematical model of ischaemic stroke outcome.

\begin{tabular}{|c|c|c|}
\hline \multicolumn{3}{|c|}{$\begin{array}{l}\text { where the constant }=-1.463 ; \mathrm{X}_{1}-\text { level of consciousness }(0-\text { intact; } \\
1 \text { - sleepiness; } 2-\text { somnolencia; } 3-\text { semi-coma; } 4-\text { coma }) ; X_{2}-\text { blood } \\
\text { glucose level; } \mathrm{X}_{3}-\text { number of leukocytes in blood (thous.); } \mathrm{X}_{4}-\mathrm{IndCL} / \\
\text { SpCL; } \mathrm{X}_{5}-\mathrm{MDA}(\mu \mathrm{mol} / \mathrm{l}) ;\end{array}$} \\
\hline Adverse outcome: & Benign outcome: & $\begin{array}{l}\text { Prognostic } \\
\text { significance: }\end{array}$ \\
\hline $\mathrm{D}>1.210$ & $\mathrm{D}<-0.355$ & $85.1 \%(p<0.001)$ \\
\hline $\mathrm{D}>3$ & $D<-1$ & $99.9 \%$ \\
\hline
\end{tabular}

The research performed made it possible to develop an algorithm for pathogenetically grounded therapy of FRP course disorders under critical states of various geneses. We have established that the indications for EC-therapy are as follows: an increase in CLIb $>130 \mathrm{mV} / \mathrm{s} \times 10^{6}$ leukocytes, CLIs with zymosan $>750 \mathrm{mV} / \mathrm{s} \times 10^{6}$ leukocytes, $\mathrm{AC}>26$, IndCL/SpCL (k/APA) > 3, and TBC-RP (MDA) $>4 \mu \mathrm{mol} / \mathrm{l}$.

\section{CONCLUSION}

The performed study has shown that in the case of stroke of different natures, accompanied by syndromes of tissue ischaemia, hypoxia, and local and systemic inflammatory reactions, we can observe the same sequence in the development of oxygen imbalance and lipid stages of FRP; we can further observe the rate of unfolding of these syndromes, and which convey the dynamics of clinical and standard laboratory indicators. The earliest markers of FRP imbalance severity are the CLIs and CLIb, which characterize the imbalance of the FRP oxygen component. In cases of increasing ischaemia, the greatest imbalance is revealed by the levels of parameters reflecting the stage of lipid peroxidation (decrease of APA and growth of MDA).

Among the patients with ischaemic stroke, the imbalance markers of FRP lipid phase were as follows: MDA increased by 1.27 times, and APA decreased by 1.07 times. In cases of haemorrhagic stroke, CLIb increased by 1.27 times, CLIs - by 1.42 times, and MDA - by 1.36 times; however, APA decreased by 1.15 times. The levels of critical MDA values were as follows: $6.39 \mu \mathrm{mol} / \mathrm{l}$ - in IS; 5.41 $\mu \mathrm{mol} / \mathrm{l}$ - in HS.

The study of FRP index dynamics, among patients with stroke of different genesis who received no EC therapy, has shown a marked imbalance in both the oxygen and lipid stages throughout the whole period of in-patient 
follow-up, with a tendency to activate FRP by the time of discharge. The early inclusion of AC/AO therapy into the complex treatment of patients with critical states of various natures and severity promotes the activation of consciousness, which advances the comparison group, the regression of neurological insufficiency by means of reducing the cerebral ischaemia zone, the reduction of disability with a change in its structure by means of decrease of severe, and the increase of good functional outcome.

The established digital boundaries of risk of adverse outcomes for various laboratory indicators became a key result of the study, making it possible to recommend the use of these indicators, as early prognostic markers of stroke course and outcomesto and to carry out the early diagnosis and prognosis of stroke. The multifactor analysis of more than 700 criteria (indicators evaluated in dynamics among patients with stroke), discriminant analysis, logistic regression and mathematical modelling allowed the identification of the formula that includes only 5 factors, the assessment of which, on the $1^{\text {st }}$ day of hospitalization, makes it possible to predict with a high degree of accuracy (more than $88 \%$ ) the outcome of a stroke. These results gives us an opportunity to timely optimize stroke therapy and to improve treatment results.

\section{REFERENCES}

1. Aliev, N.A., Bobiev, A.B., Khamidov, D.B. et al. (2015). Reosorbilakt i Latren v korrektsii endogennoi intoksikatsii i oksidantnogo stressa u bol'nykh s ostrym destruktivnym pankreatitom [Rheosorbilact and Latren in the Correction of Endogenous Intoxication and Oxidative Stress of Patients with Acute Destructive Pancreatitis]. Meditsina neotlozhnykh sostoyanii, 1(64), 57-59.

2. Asmat, U., Abad, K., \& Ismail, K. (2016). Diabetes Mellitus and oxidative Stress - A Concise Review. Saudi Pharmaceutical Journal, 24(5), 547-553.

3. Azizova, O.A., Gao, L.N., Dumikyan, A.Sh. et al. (2011). Prognosticheskoe znachenie dinamiki pokazatelei oksidantnogo stressa u bolnykh so stabilnoi ishemicheskoi boleznyu serdtsa [The Predictive Value of Dynamics of Oxidative Stress Index among Patients with Stable Coronary Heart Disease]. Kardiologiya i serdechnososudistaya khirurgiya, 4(1), 4-9.

4. Bjørklund, G., \& Chirumbolo, S. (2016). Role of Oxidative Stress and Antioxidants in Daily Nutrition and Human Health. Nutrition, 33, 311-321.

5. Bonomini, F., Rodella, L.F., \& Rezzani, R. (2015). Metabolic Syndrome, Aging and Involvement of Oxidative Stress. Aging and Disease, 6(2), 109-120.
6. Chamorro Á, Dirnagl U, Urra X, Planas AM. Neuroprotection in acute stroke: targeting excitotoxicity, oxidative and nitrosative stress, and inflammation. Lancet Neurol. 2016;15(8):869-881.

7. Chatzopoulos A, Tzani AI, Doulamis IP et al. Dynamic changes in calprotectin and its correlation with traditional markers of oxidative stress in patients with acute ischemic stroke. Hellenic J Cardiol. 2017. pii: S11099666(17)30116-1. doi: 10.1016/j.hjc.2017.07.002.

8. Chehaibi K, Trabelsi I, Mahdouani K, Slimane MN. Correlation of Oxidative Stress Parameters and Inflammatory Markers in Ischemic Stroke Patients. J Stroke Cerebrovasc Dis. 2016;25(11):2585-2593.

9. Giam, B., Kaye, D.M., \& Rajapakse, N.W. (2016). Role of Renal Oxidative Stress in the Pathogenesis of the Cardiorenal Syndrome. Heart, Lung and Circulation, 25(8), 874-880.

10. Hussain, T., Tan, B., Yin, Y., Blachier, F., Tossou, M.C., \& Rahu, N. (2016). Oxidative Stress and Inflammation: What Polyphenols Can Do for Us? Oxidative Medicine and Cellular Longevity, 2016(2016), 7432797.

11. Liu Z, Zhou T, Ziegler AC, Dimitrion P, Zuo L. Oxidative Stress in Neurodegenerative Diseases: From Molecular Mechanisms to Clinical Applications. Oxid Med Cell Longev. 2017;2017:2525967. doi: 10.1155/2017/2525967.

12. Silina, E.V., Rumyantseva, S.A., Bolevich, S.B. et al. (2011). Zakonomernosti techeniya svobodnoradikalnykh protsessov i prognoz ishemicheskogo i gemorragicheskogo insulta [The Patterns of Free Radical Processes and the Prognosis of Ischemic and Hemorrhagic Strokes]. Zhurnal nevrologii i psikhiatrii im. S.S. Korsakova, 111(12-2), 36-42.

13. Strong, K., Mathers, C., \& Bonita, R. (2007). Preventing Stroke: Saving Lives around the World. Lancet Neurology, 6, 182-187.

14. Suen, J., Thomas, J., Kranz, A., Vun, S, \& Miller, M. (2016). Effect of Flavonoids on Oxidative Stress and Inflammation in Adults at Risk of Cardiovascular Disease: A Systematic Review. Healthcare (Basel), 4(3), E69.

15. Vijayalakshmi, P., Geetha, C.S., \& Mohanan, P.V. (2013). Assessment of Oxidative Stress and Chromosomal Aberration Inducing Potential of Three Medical Grade Silicone Polymer Materials. Journal of Biomaterials Applications, 27(6), 763-772.

16. Wang D, Feng JF, Yuan GY et al. Association between chromosomal aberration of exfoliated bladder cells in the urine and oxidative stress in patients with bladder transitional cell carcinoma. Oncol Lett. 2017;14(1):137-144.

17. Žitňanová I, Šiarnik P, Kollár B et al. Oxidative Stress Markers and Their Dynamic Changes in Patients after Acute Ischemic Stroke. Oxid Med Cell Longev. 2016;2016:9761697. 